ojed.org/jis

\title{
Analysis of Social Adjustment Factors of International Students in Turkey
}

\author{
Murat Gündüz \\ Naib Alakbarov \\ Usak University, Turkey
}

\begin{abstract}
International student mobility is an important issue in many countries. In 2016, the number of international students reached 5 million worldwide. Turkey has attracted international students since the 1990s; however, the influx of such students has increased notably since 2009. In this study, we analyze factors affecting the social adjustment of international students studying at Usak University in Turkey. Participants' questionnaire responses were grouped via factor analysis, and pertinent factors affecting social adjustment were revealed through logistic regression analysis. Results indicate that feeling safe and communicating with counseling services and university lecturers can facilitate international students' social adjustment at Usak University.
\end{abstract}

Keywords: factor analysis, international students, logit model, social adjustment, Usak University

According to the UNESCO Institute for Statistics' Global Education Digest (2006), an internationally mobile student refers to an individual who has left his/her home country or birthplace to relocate to another country or territory for the purpose of studying. Students traveling to Turkey to pursue education were legally labeled foreign students in 1983; since 2011, foreign students in Turkey have been called international students. Under the coordination of the Presidency for Turks Abroad and Related Communities, Turkey published the "International Students Strategy Paper" in 2012. International students were defined thusly: "Students, who are non- 
citizens of the Republic of Turkey, coming to Turkey with a student visa or special permit with Turkey for the purpose of studying in social educational institutions at all levels and branches, [or] cultural [and] professional development of students studying on their own account or with a scholarship" (Üniversitelerarası Kurul (Turkish Interuniversity Council) [ÜAK], 2016). The number of foreign students enrolled in higher education programs worldwide grew from 0.8 million in the late 1970s to 5 million in 2016 (Organisation for Economic Cooperation and Development [OECD], 2018). This increase in foreign registration can be attributed to various internal and external factors, such as push (supporting outward mobility) and pull (supporting inward mobility) factors. As the growing needs of information-based and innovation-focused economies have spurred demand for higher education around the world, local training capacities have not grown fast enough to meet ever-increasing domestic demand. Growing economies in developing countries have caused an increasing population of middle-class children to seek educational opportunities abroad. Additionally, economic, technological, and cultural factors have led international student mobility to become substantially more economical and less irrecoverable than in the past. Initiatives at the national, regional, local, supranational, and institutional levels have also contributed to cross-border mobility (OECD, 2017). The purpose of this study is to identify issues of social adjustment among international students studying at Usak University, Turkey. This paper aims to promote the social adjustment of more than 3000 international students from approximately 90 countries who were registered at the university in 2017.

\section{INTERNATIONAL STUDENT MOBILITY IN TURKEY}

International student mobility in Turkey has grown since the 1990s. Beginning in the 1992-93 academic year, the number of students coming to Turkey on scholarship under the Grand Student Project grew dramatically (Kavak \& Baskan, 2001). The number of international students, which stood at about 48,000 four years ago, now exceeds 148,000 (Yükseköğretim Kurulu (Turkish Council of Higher Education) [YÖK], 2019). However, this figure is quite low compared to the number of international students studying in countries with leading positions in international education such as the United States, Great Britain, France, Germany, and Australia. Ebbs and flows in the number of international students in Turkey throughout the past 30 years suggest that the country has not followed a stable policy in this regard (Siyaset, Ekonomi ve Toplum Araştırmaları Vakfi (SETA Foundation for Political, Economic and Social Research) [SETA], 2017). 
Table 1: Total Inbound and Outbound International Students (World and Turkey)

\begin{tabular}{lccc}
\hline Years & $\begin{array}{c}\text { Total Inbound } \\
\text { International } \\
\text { Students } \\
\text { (Turkey) }\end{array}$ & $\begin{array}{c}\text { Total } \\
\text { International } \\
\text { Student Mobility } \\
\text { (World) }\end{array}$ & $\begin{array}{c}\text { Total Outbound } \\
\text { Internationally } \\
\text { Mobile Tertiary Students } \\
\text { Studying Abroad }\end{array}$ \\
\hline $\mathbf{1 9 9 9}$ & 18,337 & $2,009,533$ & 51,299 \\
$\mathbf{2 0 0 0}$ & 17,654 & $2,082,469$ & 51,608 \\
$\mathbf{2 0 0 1}$ & 16,656 & $2,172,735$ & 52,083 \\
$\mathbf{2 0 0 2}$ & 16,328 & $2,468,440$ & 55,457 \\
$\mathbf{2 0 0 3}$ & 12,729 & $2,678,468$ & 55,318 \\
$\mathbf{2 0 0 4}$ & 15,298 & $2,736,306$ & 55,523 \\
$\mathbf{2 0 0 5}$ & 18,166 & $2,853,455$ & 55,412 \\
$\mathbf{2 0 0 6}$ & 19,079 & $2,927,864$ & 37,452 \\
$\mathbf{2 0 0 7}$ & 19,257 & $3,102,835$ & 39,304 \\
$\mathbf{2 0 0 8}$ & 20,219 & $3,316,524$ & 44,030 \\
$\mathbf{2 0 0 9}$ & 21,898 & $3,512,753$ & 49,928 \\
$\mathbf{2 0 1 0}$ & 25,838 & $3,748,260$ & 51,888 \\
$\mathbf{2 0 1 1}$ & 31,118 & $3,940,649$ & 50,932 \\
$\mathbf{2 0 1 2}$ & 38,590 & $4,011,439$ & 48,953 \\
$\mathbf{2 0 1 3}$ & 54,387 & $4,122,176$ & 45,469 \\
$\mathbf{2 0 1 4}$ & 48,183 & $4,337,288$ & 45,326 \\
$\mathbf{2 0 1 5}$ & 72,178 & $4,606,719$ & 45,727 \\
\hline
\end{tabular}

Source: UNESCO: Outbound internationally mobile students by host region, http://data.uis.unesco.org/Index.aspx?queryid=172;OECD:http://www.oecdilibrary.org/education/education-at-a-glance-2017_eag-2017-en (16.11.2017).

\section{LITERATURE REVIEW}

\section{Social Adjustment of International Students}

Social adjustment can be defined as a psychological process that includes handling of new social standards and values for individual acceptance (Jain, 2012). Integrating into the social life of a university, a city, and a country; building an environmental network; and managing social freedoms in a new environment are important elements of social adjustment (Gerdes \& Mallinckrodt, 1994). Thus, social adjustment poses an enduring challenge for international students. These students 
may face difficulties in adapting to the host society, establishing and maintaining new social relationships, and developing a sense of belonging. According to recent studies, factors such as language barriers, cultural differences, and perceived discrimination are related to international students' challenges in adapting to a host society (Ma, 2017).

Ward and Kennedy (1993) investigated sociocultural adjustment among 178 New Zealand American Field Service students in 23 countries. Their findings revealed that students' longing for home, external locus of control, life changes, and social difficulties constituted 55\% of the variance in psychological adjustment. Searle and Ward (1990) analyzed adjustment problems among international students by distinguishing between psychological and sociocultural adaptation patterns during intercultural transition. They employed multiple regression models and discovered that $34 \%$ of the variance in psychological adjustment involved students' satisfaction when interacting with residents of the host country, sociability, life changes, and social difficulties. Additionally, $36 \%$ of the variance in sociocultural adjustment consisted of cultural distance, expected difficulty, and depression.

Once international students leave their regional social environment and arrive in the country in which they will be studying, they must adapt socially sooner or later. These students need to adjust to a new environment, socialize independently, communicate and cooperate with strangers, and cope with new environmental pressures and impressions. International students must also adapt to a new culture, individual relationships, dating etiquette, and customs. The success of these adjustments will influence how well students can build a social network (Chen \& Chen, 2009).

According to Nasir (2012), international students encounter a variety of social and academic adjustment issues in their new country. Common problems include challenges in language and communication; accommodation-related stress; and adapting to different types of cuisine, climatic conditions, and friendships. International students' academic success is directly related to resolving these problems. Newsome and Cooper (2016) analyzed international students' cultural and social adjustment process and pointed out that students studying abroad confronted a three-stage process: students initially have high expectations, then encounter culture shock, and finally develop possible adjustment strategies.

\section{Social Adjustment of International Students in Turkey}

The number of international students enrolled in higher education in Turkey has been increasing, particularly since 2009. Yet this growth has also introduced challenges related to these students' academic, social, and cultural adjustment. Köleoğlu (2018) found that international students' social adjustment issues involve economics, education, and incorrect Turkish language use. Kılıçlar, Sarı, and Seçilmiş (2012) performed factor analysis to examine adjustment problems among students coming to Turkey from the Turkic Republics and Communities and 
identified five dimensions: language problems, financial problems, sociocultural adjustment problems, orientation problems, and personal problems. These results were consistent with factors obtained by Kashima and Loh (2006) and Brisset et al. (2010). Kılıçlar, Sarı, and Seçilmiş (2012) also uncovered an inverse relationship between international students' academic achievement and language problems; that is, their academic performance declined as the extent of their language adaptation problems increased.

Cura ve Issı (2016) noted that social support positively affects the academic adjustment of international students studying in Turkey. Specifically, students exhibited a high level of academic adjustment if they had a high level of social support. Although a significant and positive correlation was observed between academic adjustment and perceived social support, academic adjustment showed a negative correlation with cultural stress.

Kağnıc1 (2012) explored international students' university adjustment on the basis of demographics (e.g., gender, age, and length of residence) and multicultural personality variables (e.g., cultural empathy, open-mindedness, flexibility, emotional stability, and social initiative). Social initiative and emotional stability contributed significantly to students' social adjustment. Although certain demographic variables did not significantly affect these students' university adjustment, five of Kağnıcı's selected multicultural personality variables (emotional initiative, emotional stability, cultural empathy and open-mindedness) did affect their adjustment. Kartal, Işık, and Yazıcı (2018) found that a sample of international students demonstrated a high level of adjustment at a public university in Turkey. Their findings indicated that variables such as gender, economic status, place of residence, and Turkish education exerted important influences on international students' academic and social adjustment.

Studies related to adjustment problems among international students studying at Turkish universities have become increasingly prevalent in recent years. Identifying and resolving such adjustment problems are essential to promoting internationalization of these universities. This study aims to investigate international students' social adjustment at Usak University. Findings also offer insight into international student adjustment at other universities in Turkey.

\section{METHOD}

This research involved a quantitative study based on a questionnaire distributed to international students enrolled at Usak University. The instrument, consisting of 117 items, was intended to measure international students' academic and social adjustment. Questionnaires were completed in person, and participants were determined using random sampling. Excluding errors and questions with no responses, 570 questionnaires were retained for analysis. This figure is substantially higher than the minimum value for a population of about 3000 students, according to sampling theory (Fox et al., 2009). Survey participants were included from all departments of Usak University; $77 \%$ of students surveyed were men, and $23 \%$ were 
women. Regarding the reliability of the questionnaire, Cronbach's alpha was 0.94, indicating high reliability.

Questionnaire items were grouped via factor analysis, after which logistic regression analysis was applied to the obtained factors. Factor analysis is a statistical technique used to decrease large numbers of variables to fewer, more meaningful variables. This approach aims to reveal hidden dimensions that are known but not directly observable while reducing the total number of variables (Karagöz, 2016). Specifically, factor analysis generates variables (i.e., factors) with labels by grouping together variables that are not explicitly related but can be used to describe an event, especially in the social and human sciences.

The linear factor model can be applied to determine the k unobservable factors that are linearly dependent on X data matrix but are independent of one another while considering the error or special factor effect. The linear factor model can be written as follows (Özdamar, 2010):

$$
\begin{aligned}
& \mathrm{X}_{1}-\mu_{1}=l_{11} \mathrm{~F}_{1}+l_{12} \mathrm{~F}_{2}+\ldots+l_{1 \mathrm{k}} \mathrm{F}_{\mathrm{k}}+\varepsilon_{1} \\
& \mathrm{X}_{2}-\mu_{2}=l_{21} \mathrm{~F}_{1}+l_{22} \mathrm{~F}_{2}+\ldots+l_{2 \mathrm{k}} \mathrm{F}_{\mathrm{k}}+\varepsilon_{2} \\
& \vdots \\
& \mathrm{X}_{\mathrm{p}}-\mu_{\mathrm{p}}=l_{\mathrm{p} 1} \mathrm{~F}_{1}+l_{\mathrm{p} 2} \mathrm{~F}_{2}+\ldots+l_{\mathrm{pk}} \mathrm{F}_{\mathrm{k}}+\varepsilon_{\mathrm{p}}
\end{aligned}
$$

where $l_{\text {ij }}$ denotes a factor loading (i.e., $i$ variable loading over $j$ factor).

Logistic regression is an extension of multiple regression analysis, wherein the dependent or output variable is categorical. In real life, cases involving categorical output variables are quite common. The logit of $\mathrm{Y}$ from $\mathrm{X}$ is predicted from the logistic model; the logit is the natural logarithm (ln) of the odds of Y. Odds refer to probability ratios $(\pi)$, namely the likelihood of $Y$ occurring to the likelihood $(1-\pi)$ of $\mathrm{Y}$ not occurring. The logistic model can be simply demonstrated through the following form (Peng et al., 2002):

$$
\text { Logit }(Y)=\text { natural } \log (\text { odds })=\ln (\pi /(1-\pi))=\alpha+\beta X
$$

Taking the antilog of the above equation, we obtain the following equation to predict the probability that an outcome of interest will occur:

$\frac{\mathrm{e}^{\alpha+\beta \mathrm{x}}}{1+\mathrm{e}^{\alpha+\beta \mathrm{x}}}$

$$
\pi=\text { Probability }(Y=\text { interest outcome } \backslash X=x \text {, a specific value of } X)=
$$

where $\alpha$ is the Y intercept, $\beta$ is the regression coefficient, and $e=(2.71828)$ is the base of the system of natural logarithms. $X$ can be categorical or continuous, whereas $\mathrm{Y}$ is always categorical.

\section{RESULTS}

\section{Factor Analysis}


The results of our factor analysis revealed 10 factors, nine of which could be labeled; the remaining factor was excluded from analysis because it was comprised of unrelated variables. Factor 1 contained 9 items; Factor 2 contained 6 items; Factor 3 contained 4 items; Factor 4 contained 3 items; Factor 5 contained 4 items; Factor 6 contained 6 items; and Factors 7, 8, and 9 each contained 3 items as indicated in Table 2 .

\section{Table 2: Factors and Variables Constituting Each Factor}

\begin{tabular}{|c|c|c|}
\hline $\begin{array}{l}\text { Factor } \\
\text { no. }\end{array}$ & Factor name & Constituent variables \\
\hline 1 & $\begin{array}{l}\text { Psychological } \\
\text { adjustment }\end{array}$ & $\begin{array}{l}\text { - I cannot control my emotions } \\
\text { - Usually I feel alone } \\
\text { - I feel very tired } \\
\text { - I make hard decisions about school } \\
\text { - I feel I have lost control of my life in general } \\
\text { - I feel more pessimistic and depressed since I } \\
\text { came to Turkey } \\
\text { - I feel culturally disengaged with the } \\
\text { environment } \\
\text { - I feel more nervous and frustrated since I came } \\
\text { to Turkey }\end{array}$ \\
\hline 2 & $\begin{array}{c}\text { Counseling } \\
\text { services }\end{array}$ & $\begin{array}{l}\text { - I think that counseling services are effective in } \\
\text { solving my problems } \\
\text { - I can reach counseling services when I want }\end{array}$ \\
\hline
\end{tabular}


- When I have a problem, I apply for counseling services

- My counselor guides me to improve my performance in my classes

- I am generally pleased with the attitudes and behaviors of my lecturers

- I am generally satisfied with the attitudes and behaviors of University employees

- I have many friends at the university

- I think that I am capable of establishing social relationships at the university

- I usually get along well with Turkish students at the university

- I usually get along well with my friends or colleagues that I am living with

$4 \quad$ Getting used to university
- I do not think I can get used to university

- I prefer to be at home rather than at the university

- I think about leaving the university and returning to my country 


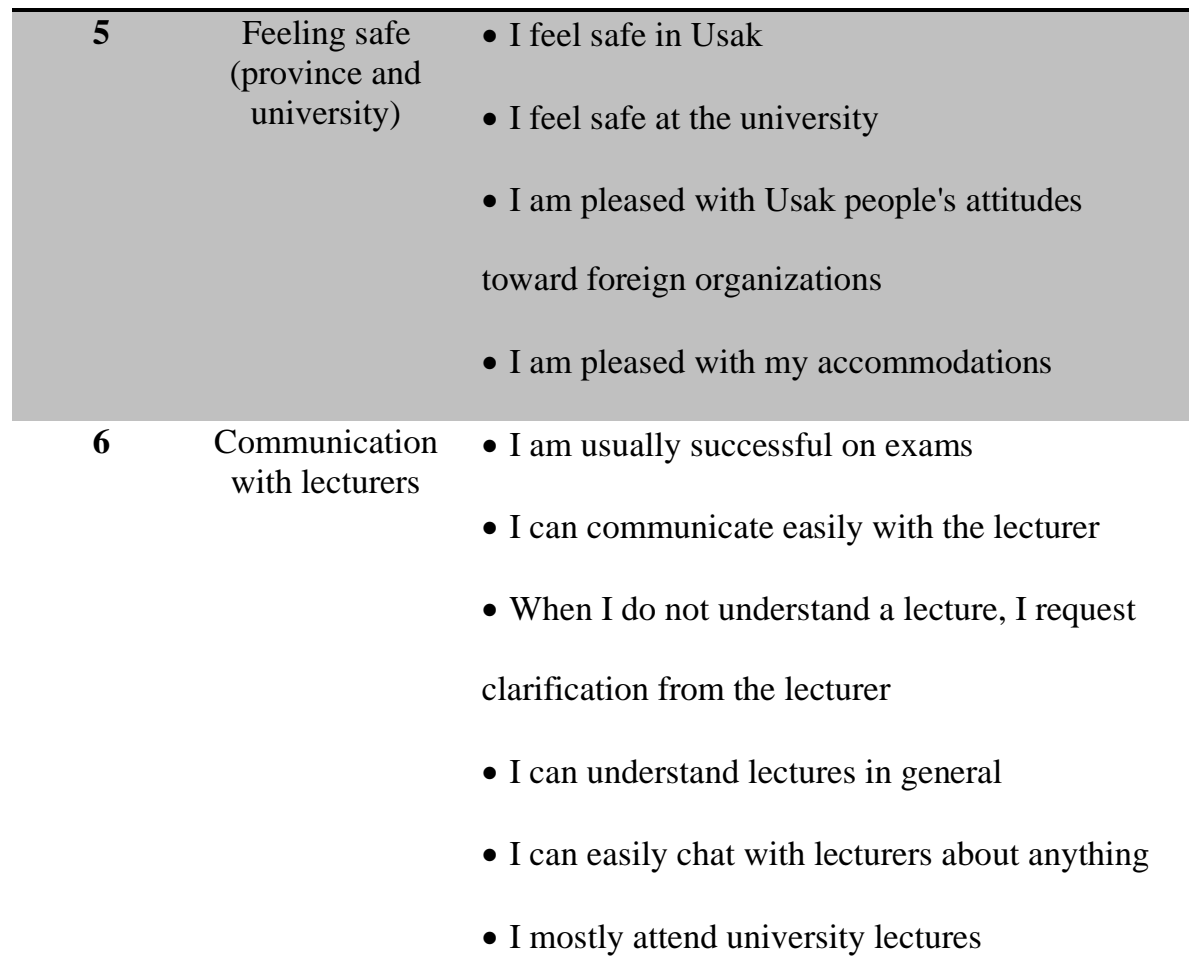

\begin{tabular}{|c|c|c|}
\hline 7 & $\begin{array}{l}\text { Skills to build } \\
\text { friendships }\end{array}$ & $\begin{array}{l}\text { - I can build friendships } \\
\text { - I can build friendships with the opposite sex } \\
\text { - I can establish friendships outside my country }\end{array}$ \\
\hline 8 & Social activities & $\begin{array}{l}\text { - I am pleased with the social opportunities } \\
\text { - I feel like I am at home even when I am at the } \\
\text { university } \\
\text { - I attend many social activities at the university }\end{array}$ \\
\hline 9 & $\begin{array}{l}\text { Discrimination } \\
\text { (province and } \\
\text { university) }\end{array}$ & $\begin{array}{l}\text { - My university friends are mostly from my own } \\
\text { country }\end{array}$ \\
\hline
\end{tabular}




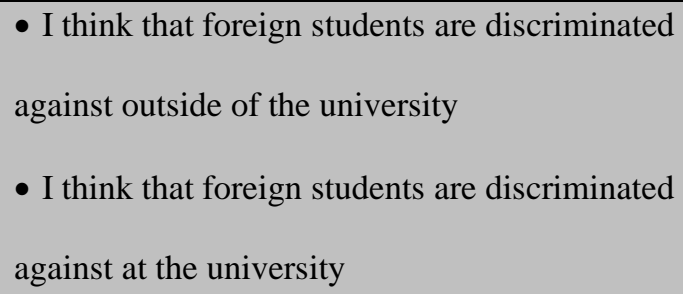

\section{Logistic Regression Analysis}

The problem of social adjustment has been examined from various dimensions in the literature. For example, Gabel, Dolan, and Cerdin (2005) considered the cultural adjustment of international managers from three dimensions. Black, Mendenhall, and Oddou (1991) used a similar method to study social adjustment via the same three dimensions investigated in Gabel, Dolan, and Cerdin(2005): sociocultural adjustment, workplace adjustment, and general adjustment. Accordingly, we analyzed international students' social adjustment in terms of Usak province, Usak University, and environment/friendship. These are dimensions meant to be analogous to sociocultural, workplace, and general adjustment, respectively. Findings appear in Tables 3-5. Table 3 presents factors affecting the provincial social adjustment of the students studying at Usak University. The item "Usak province generally meets my expectations" was taken as the dependent variable.

Table 3: Dependent Variable: "Usak Province Generally Meets My Expectations"

\begin{tabular}{lccccc}
\hline & B & $\begin{array}{c}\text { Standard } \\
\text { Error }\end{array}$ & $\begin{array}{c}\text { Wald } \\
\text { Statistic }\end{array}$ & Significance & Exp(B) \\
\hline Factor1 & .182 & .194 & .878 & .349 & 1.200 \\
Factor2 & .838 & .206 & 16.618 & .000 & 2.312 \\
Factor3 & .315 & .197 & 2.552 & .110 & 1.370 \\
Factor4 & .142 & .179 & .630 & .427 & 1.153 \\
Factor5 & 1.158 & .203 & 32.628 & .000 & 3.182 \\
Factor6 & .736 & .182 & 16.399 & .000 & 2.087 \\
Factor7 & .404 & .174 & 5.366 & .021 & 1.498 \\
Factor8 & .999 & .208 & 23.119 & .000 & 2.717 \\
Factor9 & .499 & .198 & 6.332 & .012 & 1.647 \\
\hline
\end{tabular}




\begin{tabular}{llllll}
\hline Constant & .908 & .190 & 22.963 & .000 & 2.480 \\
\hline
\end{tabular}

In the model, the reference category was that Usak province generally did not meet international students' expectations (i.e., students did not socialize). Results of the omnibus test indicated that the model was significant at the 5\% level according to the Chi-square test. The degree of disclosure of the dependent variable of the Nagelkerke $\mathrm{R}_{2}=0.51$. The correct estimation of the model was $80.8 \%$, and all variables had positive values; these findings reflect improved provincial social adjustment among surveyed international students because of changes in relevant variables. Factor 5 (Feeling safe), Factor 8 (Social activities), Factor 2 (Counseling services), and Factor 6 (Communication with lecturers) had the greatest impacts of all factors. Feeling safe exerted the strongest effect on social adjustment. Factor 9 related to expressing discrimination was found to increase social adjustment, but this result was unexpected. The provincial social adjustment variable was particularly influenced by institutional factors. Regulation of institutional factors to increase social adjustment also increased the social adjustment of those expressing discrimination. This pattern underscores the importance of institutional arrangements in countries' efforts to attract international students. International students can enhance their social adjustment when engaging in social activities, counseling, and productive communication with university lecturers, even when they think they are being discriminated against.

Table 4 lists factors affecting university-based social adjustment of international students at Usak University. The item "I think that I have made the right decision by choosing Usak University" served as the dependent variable.

Table 4: Dependent Variable: "I think that I have made the right decision by choosing Usak University"

\begin{tabular}{lccccc}
\hline & $\mathbf{B}$ & $\begin{array}{c}\text { Standard } \\
\text { Error }\end{array}$ & $\begin{array}{c}\text { Wald } \\
\text { Statistic }\end{array}$ & Significance & $\operatorname{Exp(B)}$ \\
\hline Factor1 & -.290 & .236 & 1.510 & .219 & .748 \\
Factor2 & .693 & .222 & 9.800 & .002 & 2.001 \\
Factor3 & -.085 & .212 & .162 & .687 & .918 \\
Factor4 & -.390 & .225 & 2.996 & .083 & .677 \\
Factor5 & .944 & .230 & 16.916 & .000 & 2.571 \\
Factor6 & .449 & .209 & 4.602 & .032 & 1.567 \\
\hline
\end{tabular}




\begin{tabular}{lccccc}
\hline Factor7 & .401 & .204 & 3.866 & .049 & 1.493 \\
Factor8 & .532 & .206 & 6.662 & .010 & 1.703 \\
Factor9 & .419 & .222 & 3.557 & .059 & 1.521 \\
Constant & 2.435 & .256 & 90.647 & .000 & 11.421 \\
\hline
\end{tabular}

In the model, the reference category consisted of students who did not socialize at the university (i.e., lack of agreement with the item "I have made the right decision by choosing Usak University"). The omnibus test indicated that the model was significant at the 5\% level according to the Chi-square results. The degree of disclosure of the dependent variable Nagelkerke $\mathrm{R}_{2}=0.35$, and the correct estimation of the model was $90.3 \%$.

All variables in the model demonstrated positive values except for those in Factor 1 (Psychological adjustment), Factor 3 (Making friends), and Factor 4 (Getting used to university). Variables in Factors 1 and 3 were statistically insignificant, whereas those in Factor 4 was significant at only 10\%. The most important variable affecting international students' social adjustment at Usak University involved Factor 5 (Feeling safe). Another important variable affecting dependent variable was counseling services. Discrimination was significant at the $10 \%$ level and appeared to promote social adjustment in the university, which was unexpected. However, this finding implies that positive institutional factors will positively affect international students' social adjustment even in the face of discrimination. In this case, institutional regulations can positively influence international students by minimizing potential discrimination. Even if international students encounter discrimination, institutional factors can increase these students' social adjustment to Usak University.

Table 5 displays factors affecting international students' social adjustment relative to their environment and friendships when studying at Usak University. The dependent variable was the item "I have a lot of friends who share my problems and with whom I can communicate."

Table 5: Dependent Variable: "I have a lot of friends who share my problems and with whom I can communicate"

\begin{tabular}{lccccc}
\hline & B & $\begin{array}{c}\text { Standard } \\
\text { Error }\end{array}$ & $\begin{array}{c}\text { Wald } \\
\text { Statistic }\end{array}$ & Significance & $\operatorname{Exp(B)}$ \\
\hline Factor1 & -.067 & .166 & .165 & .685 & .935 \\
Factor2 & .364 & .151 & 5.763 & .016 & 1.439 \\
Factor3 & .916 & .177 & 26.867 & .000 & 2.500 \\
\hline
\end{tabular}




\begin{tabular}{lccccc}
\hline Factor4 & .560 & .164 & 11.708 & .001 & 1.750 \\
Factor5 & .411 & .151 & 7.436 & .006 & 1.508 \\
Factor6 & .423 & .156 & 7.367 & .007 & 1.526 \\
Factor7 & .210 & .149 & 1.975 & .160 & 1.233 \\
Factor8 & .072 & .154 & .219 & .640 & 1.075 \\
Factor9 & -.103 & .159 & .414 & .520 & .903 \\
Constant & 1.163 & .160 & 52.878 & .000 & 3.199 \\
\hline
\end{tabular}

In the model, the reference category included students who did not have many friends who shared their problems and with whom they could communicate (i.e., limited social adjustment in terms of the environment/friendships). Findings from the omnibus test reveal that the model was significant at the 5\% level according to the Chi-square results. The degree of disclosure of the dependent variable of the Nagelkerke $\mathrm{R}_{2}=0.31$. The correct predict degree of the model was $80.3 \%$.

In the model, all variables aside from those in Factor 1 (Psychological adjustment), Factor 7 (Skills to build friendships), Factor 8 (Social activities), and Factor 9 (Discrimination) were statistically significant. Factors 1 and 9 showed negative values. As expected, Factor 3 (Making friends) was most influential in international students' social adjustment. The model results revealed that variables in Factor 4 (Getting used to university), Factor 5 (Feeling safe), and Factor 6 (Communication with lecturers) significantly influenced international students' social adjustment. Therefore, establishing friendships, getting used to university, communicating with university lecturers, and feeling self were the most important variables shaping international students' social adjustment.

\section{DISCUSSION}

In this study, factors affecting the social adjustment of international students at Usak University in Turkey were analyzed. Turkey has attracted international students since the early 1990s; however, the number of international students has not remained stable since. Although international students in Turkey are predominantly from countries that are culturally similar to Turkey, social adjustment remains an important issue.

Our results reveal that feeling safe, participating in social activities, using counseling services, and communication with lecturers were important variables influencing international students' adaptation to their place of residence. Interestingly, feeling safe was the most crucial variable affecting provincial social adjustment. The primary variable informing social adjustment to the university was feeling safe in the university and province. Another important variable influencing the dependent 
variables was counseling services. In addition to these variables, social activities, communication with lecturers, and skills to build friendships also influenced students' social adjustment.

As expected, making friends was the most effective factor in social environment adjustment. According to the model results, adapting to college, effective communication skills, and feeling safe each exerted substantial impacts on international students' environmental adaptation. As a result, friendship, adjustment to college, strong communication with lecturers, and self-confidence were the most important variables affecting international students' social adjustment at Usak University. Language barriers for international students in Turkey did not appear to be a major problem, as these students often come to Turkey from areas that share close cultural and historical relations with the country.

Our findings suggest that measures to increase the institutionalization of international student mobility in Turkey will positively affect international students' social adjustment. These results echo those of Ugwu and Adamuti-Trache (2017), who determined that institutional initiatives affect sociocultural and academic support of international students.

\section{CONCLUSIONS AND IMPLICATIONS}

Our analysis indicated that the most important factor in terms of international students' social adjustment to Usak University, the province, and friendships/environment was to feel safe in the university and province. In addition, counseling, communication with lecturers, and social activities further enhanced students' social adjustment.

The results also show that institutionalization is important, as evidenced by examples of successful international students. Nasir (2012) argued that, to facilitate international students' adjustment, they should have the opportunity to interact with people of the country in which they are studying. Through educational institutions, orientation courses, and appropriate social activities, international students can learn about the culture of the country they are visiting. The host country should also strive to understand and recognize cultural diversity so international students can adjust more easily to their new landscape.

A limitation of this study is that only students at the University of Usak were considered for analysis. Although the results do not represent all universities in Turkey, the study offers important conclusions that can benefit educational researchers and administrators. This study can be expanded in the future by considering Turkey's regional characteristics, thus ensuring a more comprehensive study that is applicable to wider Turkey. 


\section{REFERENCES}

Black, S., Mendenhall, M. \& Oddou, G. (1991). Toward a comprehensive model of international adjustment: An integration of multiple theoretical perspectives. Academy of Management Review, 16, 291-317.

Brisset, C., Safdar, S., Lewis, J. R., \& Sabatier, C. (2010). Psychological and sociocultural adaptation of university students in France: The case of Vietnamese international students. International Journal of Intercultural Relations, 34(4), 413-426.

Chen, Y. F., \& Chen, H. J. (2009). A study on international student adjustment from academic, social and cultural viewpoints in Taiwan. In International Conference on Business Management and Information Technology Application (BMITA2009).

Clark, N. (2009, September). What defines an international student? A look behind the numbers. WENR: World Education News and Reviews. Retrieved from https://wenr.wes.org/2009/09/wenr-september-2009-feature

Cura, Ü., \& Işık, A. N. (2016). Impact of acculturative stress and social support on academic adjustment of international students. Education \& Science/Egitim ve Bilim, 41(184), 333-347.

Fox, N., Hunn, A., \& Mathers, N. (2009). Sampling and sample size calculation. East Midlands/Yorkshire: the National Institutes for Health Research. Research Design Service for the East Midlands/Yorkshire \& the Humber.

Gabel, R. S., Dolan, S. L. \& Cerdin, J. L. (2005). Emotional intelligence as predictor of cultural adjustments for success in global assignments. Career Development International, 10(5), 375-395.

Gerdes, H., \& Mallinckrodt, B. (1994). Emotional, social and academic adjustment of college students: A longitudinal study of retention. Journal of Counseling \& Development, 72(3), 281-288.

Jain, T. (2012). Social adjustment is an effort made by an individual to cope with standards, values and needs of a society. Retrieved from http://www.preservearticles.com/2011082611930/social-adjustment-is-aneffort-made-by-an-individual-to-cope-with-standards-values-and-needs-of-asociety.html

Kağnıcı, D. Y. (2012). The role of multicultural personality in predicting university adjustment of international students in Turkey. International Journal for the Advancement of Counselling, 34(2), 174-184.

Karagöz, Y. (2016). SPSS ve AMOS 23 uygulamalı istatistiksel analizler. [SPSS and AMOS 23 applied statistical analysis], Ankara: Nobel Yayın.

Kartal, A. Y., Cansu I., \& Yazıcı, S. (2018). Bir Kamu Üniversitesinde Öğrenim Gören Uluslararası Öğrencilerin Sosyal ve Akademik Uyumlarını Etkileyen Faktörlerin Belirlenmesi [Determining the Factors Affecting the Social and 
Academic Adjustment of International Students Studying at a Public University]. Zeynep Kamil Tıp Bülteni, 49(1), 1-5.

Kashima, E. S., \& Loh, E. (2006). International students' acculturation: effects of international, conational, and local ties and need for closure. International Journal of Intercultural Relations, 30(4), 471-485.

Kavak, Y., \& Baskan, G. A. (2001). Türkiye'nin Türk Cumhuriyetleri, Türk ve akraba topluluklarına yönelik eğitim politika ve uygulamaları [Educational Policies and Applications of Turkey Towards Turkıc Republics and Communities]. Hacettepe Üniversitesi Eğitim Fakültesi Dergisi, 20(20), 92-103.

Kılıçlar, A., Sarı, Y., \& Seçilmiş, C. (2012). The Effects of the Problems Faced by Students from the Turkish World on Their Academic Success: The Case of Tourism Students. Bilig, 61, 157-172.

Köleoğlu, N. (2018). Uluslararası öğrencilerin sosyal uyum problemini belirlemede log-lineer model kullanımı [The use of the Log-Linear Model to Determining the Social Adjustment Problem of Internatioanal Students]. Uluslararast Iktisadi ve İdari Incelemeler Dergisi, 18. EYI Special Issue, 101-116.

Ma, J. (2017). Cooperative activity as mediation in the social adjustment of Chinese international students. Journal of International Students, 7(3), 856-875.

Mahmood, H., \& Beach, D. (2018). Analysis of acculturative stress and sociocultural adaptation among international students at a non-metropolitan university. Journal of International Students, 8(1), 284-307.

Nasir, M. (2012). Effects of cultural adjustment on academic achievement of international students. Journal of Elementary Education, 22(2), 95-103.

Newsome, L. K., \& Cooper, P. (2016). International students' cultural and social experiences in a British University: "such a hard life [it] is here". Journal of International Students, 6(1), 195-215.

Organisation for Economic Cooperation and Development. (2017). Education at a glance 2017: OECD indicators. Retrieved from http://www.oecd.org/education/education-at-a-glance-19991487.htm

Organisation for Economic Cooperation and Development. (2018). Education at a Glance 2018: OECD indicators. Retrieved from https://www.oecdilibrary.org/education/education-at-a-glance-2018_eag-2018-en

Özdamar, K. (2010). Paket programlar ile istatistiksel veri analizi II (çok değişkenli analizler) [Statistical data analysis with package programs II (multivariate analysis)], Kaan Kitabevi, 7. Baskı, Eskişehir.

Peng, C. Y. J., Lee, K. L., \& Ingersoll, G. M. (2002). An introduction to logistic regression analysis and reporting. The Journal of Educational Research, 96(1), 3-14.

Pruitt, F.J. (1978). The adaptation of African students to American society, International Journal of Intercultural Relations, 2, 90-118.

Searle, W., \& Ward, C. (1990). The prediction of psychological and sociocultural adjustment during cross-cultural transitions. International Journal of Intercultural Relations, 14(4), 449-464. 
Siyaset, Ekonomi ve Toplum Araştırmaları Vakfi (SETA), (2017). 2017'de Türkiye [Turkey in 2017], ISBN: 978-975-2459-50-2.

Ugwu, D. N., \& Adamuti-Trache, M. (2017). Post-graduation plans of international science and engineering doctoral students attending US universities. Journal of International Students, 7(1), 1-21.

UNESCO. (2006). Global education digest 2006, UIS, Montreal, Canada, Institute for Statistics. Retrieved from http://data.uis.unesco.org/ Index.aspx?queryid=172

Üniversitelerarası Kurul. (2016). Türkiye'de Yükseköğretim ve Uluslararasılaşma. [Higher Education and Internationalization in Turkey] Say1 2. Retrieved from http://cdn.hitit.edu.tr/hitit/files/23530_1610041532492.pdf .

Ward, C., \& Kennedy, A. (1993). Psychological and socio-cultural adjustment during cross-cultural transitions: A comparison of secondary students overseas and at home. International Journal of Psychology, 28(2), 129-147.

Yükseköğretim Kurulu. (2019). YÖK Başkanı Saraç: "Doktoralı insan kaynağımızı arttırmalıyız" [Chairman of the Council of Higher Education Saraç: "We should increase our human resources with doctorate"], https://basin.yok.gov.tr/InternetHaberleriBelgeleri/\%C4\%B0nternet\%20Haber \%20Belgeleri/2019/155_doktorali_insan_kaynagini_artirmaliyiz.pdf.

Zhai, L. (2002). Studying international students: Adjustment issues and social support. San Diego, CA: University of California, Office of Institutional Research. Retrieved from web:https://eric.ed.gov/?id=ED474481.

MURAT GÜNDÜZ, $\mathrm{PhD}$, is an assistant professor in the Department of Econometrics at Usak University. His major research interests lie in the area of statistical research. Email: murat.gunduz@usak.edu.tr

NAIB ALAKBAROV, $\mathrm{PhD}$, is an assistant professor in the Department of Economics at Usak University. His major research interests lie in the area of social sciences. Email: naib.alakbarov@usak.edu.tr 